\title{
SKALNÍ MÍSY VOTICKÉ VRCHOVINY
}

\author{
Pavla Draxlerová, Jiř́i Rypl
}

\begin{abstract}
The study presents a part of the results from the field work, which was part of the Bachelor Thesis on the theme - Weathering pits of Votická vrchovina Highlands. It presents a general characteristic of weathering pits in selected localities - Kněz u Hrazan, Husova kazatelna and Čertovo bremeno and the results of the measurements of the fissure system and the direction and slope of the bottoms of weathering pits. By comparing them, the question was answered: whether the orientation of the bottoms of weathering pits matches the orientation of the fissure system in the given locality. Fissure diagrams and stereograms show the results of the measurements.
\end{abstract}

Keywords: Votická vrchovina Highlands, rock landforms, weathering pits, field work

\section{Úvod}

Skalní mísy byly dřive vnímány jako umělý tvar, proto byly opředeny řadou pověstí (Chábera, 2000). Kromě legend jsou i historické záznamy o jejich praktickém využití, např. během třicetileté války některé skalní mísy v lesích kolem Vltavy byly používány k tlučení krup z obilí nebo v okolí Milevska k pálení kolomazi (Chábera 2000). Dnes již víme, že jde o přírodní tvar, na němž se podílí mechanické, chemické a biologické zvětrávání (např. Chábera, 2000; Migoń, 2006). Skalní mísa je mikroformní tvar reliéfu, který se vytváří na vodorovných nebo mírně ukloněných skalních plochách a mívá kruhový nebo oválný tvar (např. Demek, 1987; Migoń, 2006; Huggett, 2007). Dokonale vyvinuté tvary mís se vyskytují hlavně v žulových horninách, ale i v jiných krystalických horninách nebo klasických sedimentech (např. Migoń, 2006; Huggett, 2007).

Pro tuto studii byla vybrána oblast Votická vrchovina, která je z pohledu skalních mís relativně málo prozkoumaná. Skalními mísami v dané oblasti se dřive v podstatě zabýval pouze Chábera (např. 1955; 1992). Vlastní terénní průzkum proběhl ve třech vybraných lokalitách - Kněz u Hrazan, Husova kazatelna a Čertovo břemeno. Polohu lokalit v oblasti Votická vrchovina zobrazuje mapa 1. 
Mapa 1: Geomorfologické okrsky a lokality skalních mís Votické vrchoviny

Map 1: Geomorphological districts and locality of weathering pits in area of Votická vrchovina Highlands

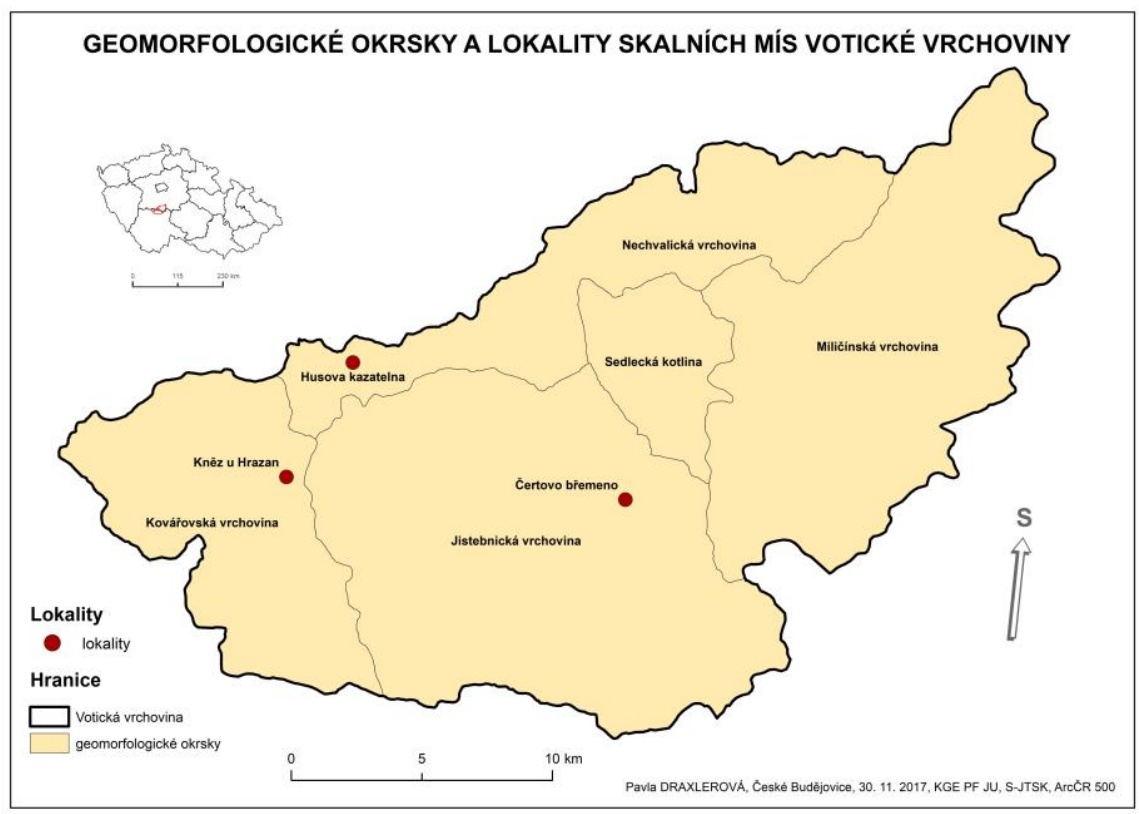

Zdroj: Autori, 2017

\section{Cíle a hypotézy}

Hlavním cílem studie bylo zmapovat výskyt a stav skalních mís ve Votické vrchovině, zaměřit se na jejich celkovou problematiku a charakteristiku ve vybraných lokalitách. Dále potvrdit nebo vyvrátit zvolené hypotézy o jejich vzniku a vývoji.

$\mathrm{Na}$ základě prostudované literatury o geologickém a geomorfologickém vývoji Votické vrchoviny, skalních mísách a zvětrávání žulových povrchů, např. Chábera (1961), Votýpka (1964), Twidale (1971), Chlupáč a kol. (2002), Migoń (2006), Drábek (2007), Norwick (2012), Rypl a kol. (2016, 2017) apod., byly vyvozeny hypotézy, které byly pak ověřovány při terénním průzkumu.

První hypotéza byla zaměřena na nehomogenitu horniny, která hraje významnou roli při vytváření zárodečných prohlubní skalních mís a výrazně se projevuje u hrubozrnných až porfyrických žul (Votýpka, 1964), u nichž dochází k rozdílnému zvětrávání jednotlivých složek nerostů (Migoń, 2006). Druhá hypotéza byla postavena na přítomnosti mechů a lišejníků, které mají v místech 
narušeného povrchu skalních mís způsobovat odlupování vrstev a rozpad žuly (Norwick, 2012), a tím zahájit vznik malých depresí (Twidale, 1971). Třetí hypotéza vycházela z tvrzení, že k zvětrávání skalních mís napomáhá prrítomnost stálé hladiny vody v míse (Migoń, 2006), která musí mít možnost stagnovat, aby se její účinek nejvíce projevil (Chábera, 1961, 2000). Podkladem pro čtvrtou hypotézu byl názor Migońa (2006), že skalní mísy se nachází hlavně na vrcholových skalních plošinách a že méně častý až vzácný je výskyt na samostatných balvanech. Poslední hypotézou je ověření shody směru orientace den skalních mís a puklinového systému lokality.

\section{Metodika}

Metodika studie obsahuje teoretickou část a vlastní terénní průzkum. Teoretická část se zaměřila na obecnou fyzickogeografickou charakteristiku Votické vrchoviny z hlediska geologie, geomorfologie, pedologie, klimatologie, hydrologie a biogeografie, dále na charakteristiku mezoformních a mikroformních tvarů ve vybraných lokalitách. Základem pro zpracování byla dostupná česká literatura, např. Chábera (1955, 1961, 1985), Quitt (1970), Vlček a kol. (1984), Rubín, Balatka a kol. (1986), Chlupáč a kol. (2002), Pavlíček (2005), Demek, Mackovčin a kol. (2006), Drábek (2007), Tomášek (2007), Culek a kol. (2013), Petránek a kol. (2016). Dále bylo čerpáno ze zahraniční literatury Twidale (1971), Goudie (2004), Migoń (2006), Norwick (2012) apod. v souvislosti s vývojem mezoformních a mikroformních tvarů, hlavně skalních mís, a s procesy zvětrávání žulových povrchů.

Vlastní terénní průzkum proběhl na přelomu léta a podzimu v srpnu až ř́ijnu 2017. Byl zaměřen na lokalizaci skalních mís na skalních tvarech a jejich zaměření pomocí GPS. U každé skalní mísy byl zaznamenáván její rozměr (délka, šířka, hloubka) a tvar, dále sklon a směr dna skalní mísy a byl př́ípadně identifikován odtokový žlábek (šiŕǩk, směr, sklon). Byla také pořízena jejich fotodokumentace, např. obr. 1 a 2 . Veškerá měření byla prováděna pro přesnost dat třikrát. Polohu jednotlivých skalních mís ve vybraných lokalitách zobrazují mapy vytvořené v programu ArcGIS.

Součástí měření byl i puklinový systém skalních tvarů $\mathrm{v}$ jednotlivých lokalitách. Z měření puklinového systému (směr a sklon puklin) byl vytvořen za každou lokalitu v programu Microsoft Excel růžicový puklinový diagram, který vycházel z průměru naměřených hodnot a jejich četnosti. Následně byl použit k vyhodnocení primárního a sekundárního směru puklin.

Tři původní naměřené hodnoty pro směr a sklon den skalních mís byly zaneseny do programu Stereonet k vytvoření stereogramů, které pomocí bodů a průsečnic znázorňují sklon (body) a směr (průsečnice) den skalních mís. Vzájemné porovnání diagramů a stereogramů přispělo k zodpovězení otázky, zda se shoduje nebo neshoduje orientace den skalních mís s puklinovým systémem v dané lokalitě. 
Vzhledem k rozsahu měření jednotlivých vlastností skalních mís nebyly všechny číselné výsledky zaneseny do dané studie. Lze je však najít v bakalářské práci.

Obr. 1: Skalní mísa č. 3 - lokalita Kněz u Hrazan

Figure 1 : Weathering pit No. 3 - the locality Kněz u Hrazan

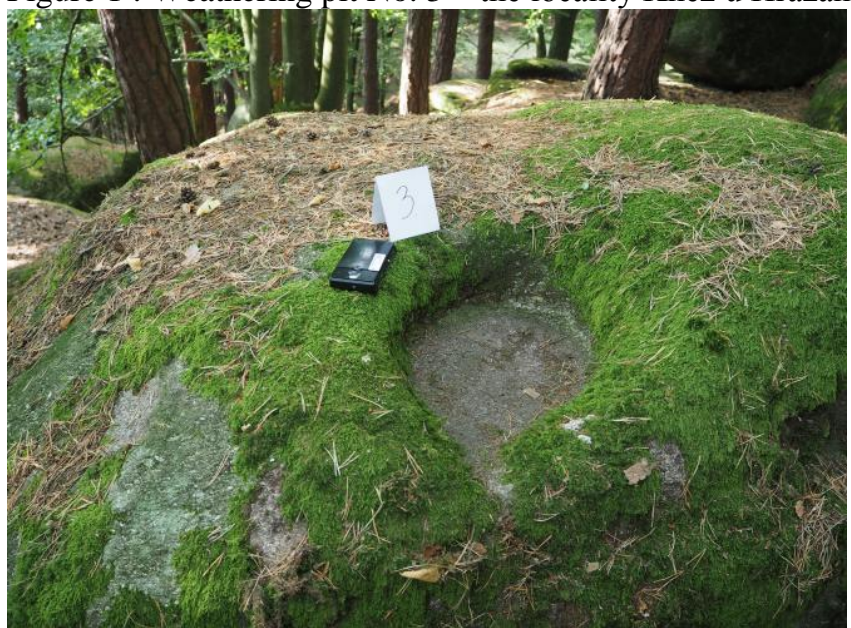

Zdroj: Autori, 2017

Obr. 2: Skalní mísa č. 10 - lokalita Husova kazatelna

Figure 2: Weathering pit No. 10 - the locality Husova kazatelna

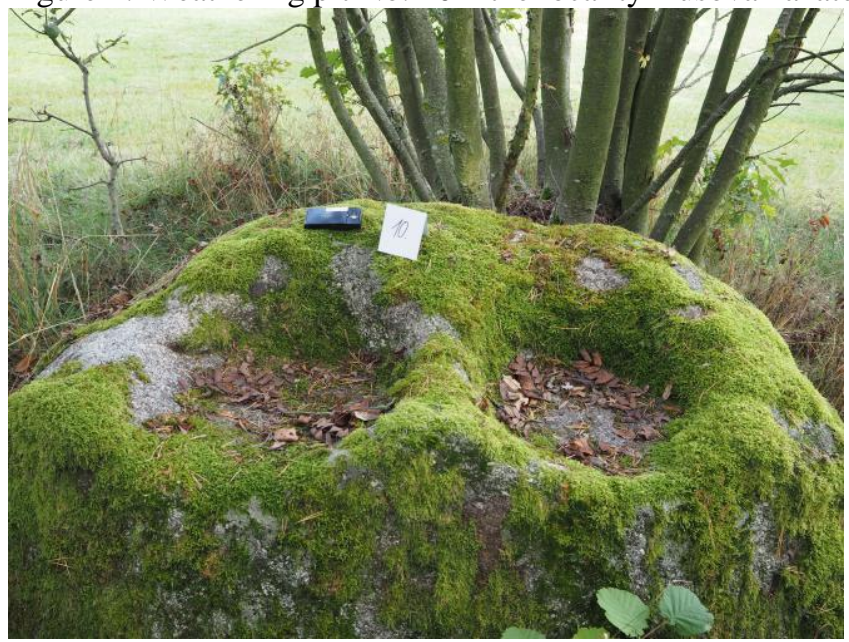

Zdroj: Autori, 2017 


\section{Výsledky měření}

Pro terénní průzkum byla zvolena tři katastrální území, kde se nachází vybrané lokality - Hrazany (lokalita Kněz u Hrazan), Petrovice (lokalita Husova kazatelna) a Jistebnice (lokalita Čertovo břemeno). Daná katastrální území se nachází v západní a střední části Votické vrchoviny. Z hlediska geomorfologického zařazení se vybrané lokality řadí do geomorfologického podcelku Votická vrchovina, jež je součástí geomorfologického celku Vlašimská pahorkatina, která je dále řazena do geomorfologické oblasti Středočeské pahorkatiny a ta je součástí Česko-moravské subprovincie (Demek, Mackovčin a kol., 2006).

\section{Knе̌z u Hrazan}

Kněz u Hrazan byl vyhlášen v roce 1985 za př́rodní památku o rozloze 5 ha se samostatným balvanovým mořem o rozloze 0,28 ha a v roce 1994 jako významná geologická lokalita (UHUL, 2001; ČGS, 2010). Lokalita se rozkládá v zalesněném prostoru na jihovýchodním svahu vrchu Březina $(575 \mathrm{~m} \mathrm{n}$. m.) a nachází se zde nahromaděné žulové balvany (balvanové moře) a volně roztroušené žokovité balvany z porfyrické amfibol-biotitické melanokratní žuly typu Čertovo břemeno (ČGS, 2010).

V lokalitě bylo zjištěno na jednotlivých balvanech celkem 9 skalních mís, jejich rozmístění zobrazuje mapa 2 . Všechny nalezené skalní mísy měly odtokový žlábek, většina byla oválného tvaru a vykazovala vysoký stupeň vývoje. Tři skalní mísy byly znatelně vidět, jedna s vodou a dvě s minimálním obsahem biologického materiálu. Ostatní mísy byly zaneseny vrstvou mechu a dalšího biologického materiálu. Jednou bylo nalezeno vzájemné propojení skalních mís a jednou byly dvě skalní mísy těsně vedle sebe. Největší mísa v lokalitě (mísa č. 4) měla rozměry 106 x 65 x $18 \mathrm{~cm}$ a nejmenší mísa (mísa č. 2) měla rozměry 26 x 15 x $5 \mathrm{~cm}$.

V rámci šetření zde bylo provedeno zaměření 62 puklin a jejich hodnoty byly zaneseny do puklinového diagramu (graf 1), z něhož vyplývá, že v lokalitě převládá jako primární směr ZSZ-VJV $\left(300^{\circ} / 120^{\circ}\right)$ s následným sekundárním směrem SSV-JJZ $\left(30^{\circ} / 210^{\circ}\right)$, primární a sekundární směr jsou na sebe kolmé. Hodnoty spojené $\mathrm{s}$ velikostí směrů a sklonů den skalních mís byly přeneseny do stereogramu (graf 2), který obsahuje tři naměřené původní hodnoty pro směr a sklon dna u každé skalní mísy. Z něho vyplývá, že dna mís vykazují sklon od $0^{\circ}$ (resp. $2^{\circ}$ ) do $14^{\circ} \mathrm{v}$ převaze ve směru Z-V a druhotně ve směru SV-JZ. Při porovnání puklinového systému se směrem den skalních mís lze konstatovat shodu v obecném směru SV-JZ. 
Mapa 2: Výskyt skalních mís v lokalitě Kněz u Hrazan v roce 2017

Map 2: The occurrence of weathering pits in the locality Kněz u Hrazan in 2017

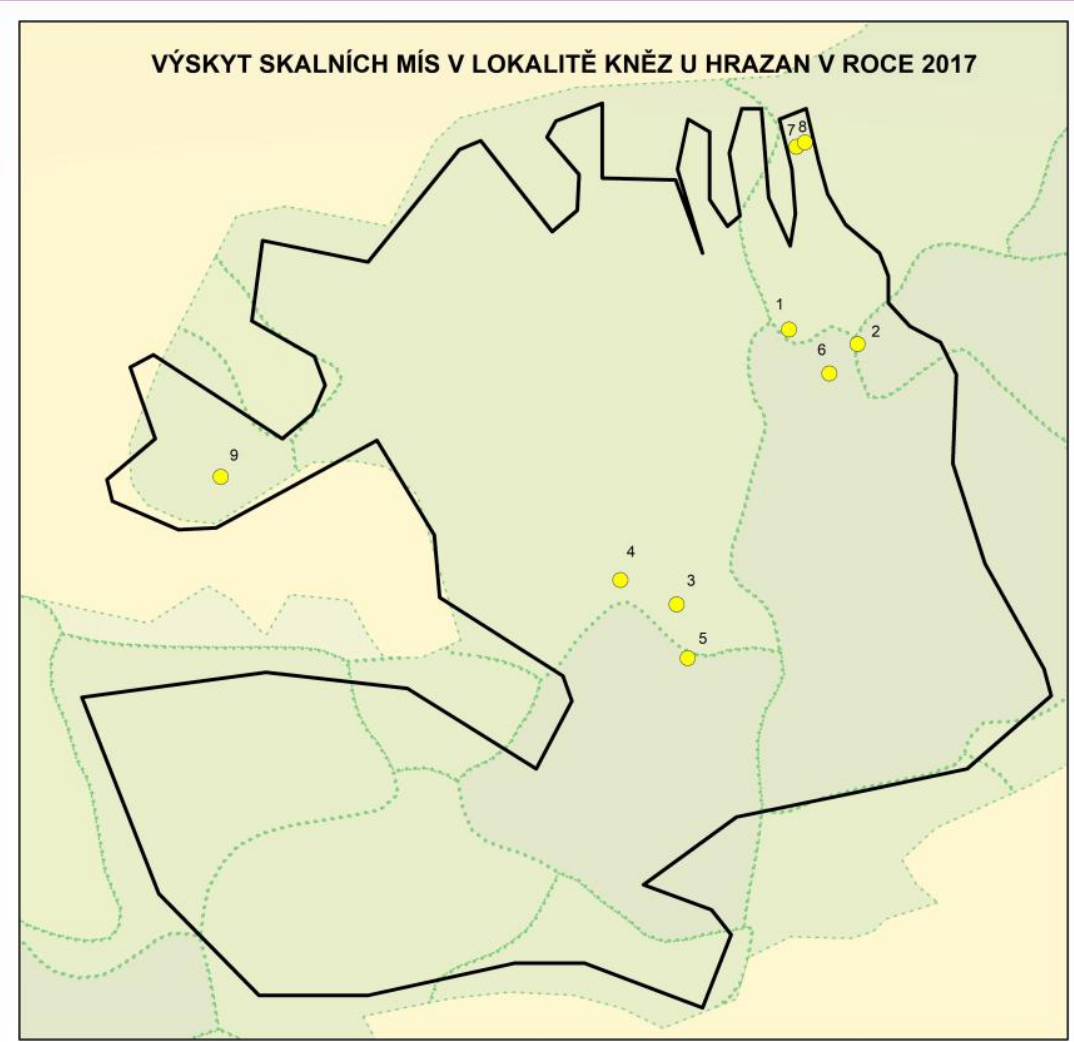

Pokryv

Trvalý travni porost

Lesni púda se stromy - vysoké přes $20 \mathrm{~m}$

Lesni pũda se stromy - vysoké od 8 do $20 \mathrm{~m}$

Lesni púda se stromy - vysoké od 2,5 do $8 \mathrm{~m}$

Lesni püda se stromy - vysoké do $2,5 \mathrm{~m}$

Skalni misy

skalni misy

Hranice lokality

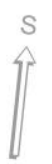

$\square$ hranice Kněz u Hrazan 
Graf 1: Puklinový diagram - lokalita Kněz u Hrazan

Graph 1: The fissure diagram - locality Kněz u Hrazan

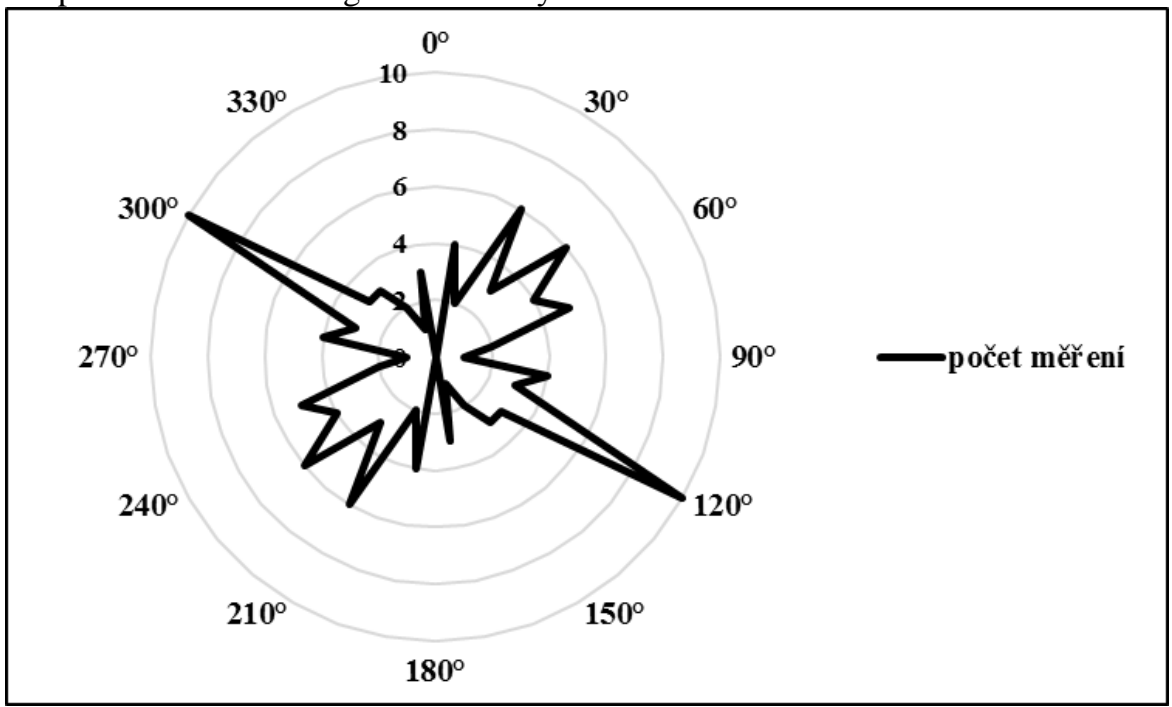

Zdroj: Autori, 2017

Graf 2: Stereogram skalních mís - Kněz u Hrazan

Graph 2: Stereogram of Weathering pits - Kněz u Hrazan

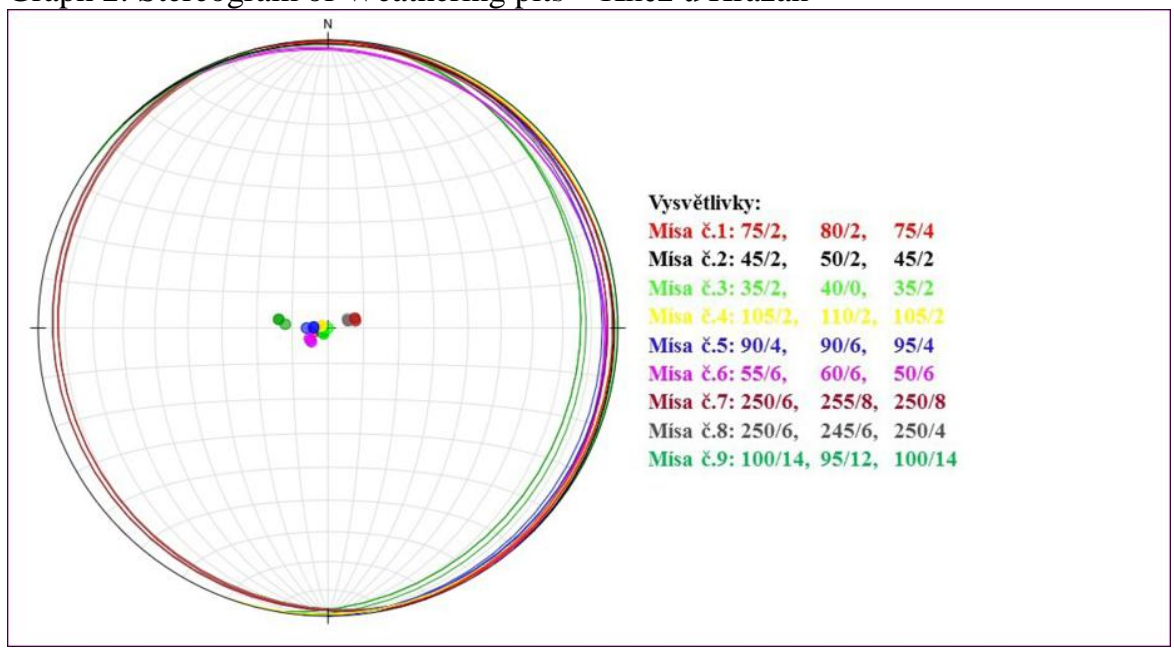

Zdroj: Autori, 2017 


\section{Husova kazatelna}

Výrazným bodem lokality je stejnojmenný viklan, který je označován jako nekorunovaný král mezi viklany Středočeské pahorkatiny na Sedlčansku (Vítek, 2004). S účinností od 1977 byla celá lokalita o rozloze 9,07 ha vyhlášena prrírodní památkou (UHUL, 2001). V okolí viklanu se nachází řada dalších větších nebo menších balvanů označovaných jako kamenné stádo. Některé z balvanů získaly lidová pojmenování, např. Zkamenělá žába, Pecen chleba či Hřib (UHUL, 2001).

V lokalitě bylo zjištěno 16 skalních mís oválného nebo kruhového tvaru v různém stádiu vývoje, přičemž většina byla s odtokovým žlábkem. Rozmístění mís zobrazuje mapa 3.

Mapa 3: Výskyt skalních mís v lokalitě Husova kazatelna v roce 2017 Map 3: The occurrence of weathering pits in the locality Husova kazatelna in 2017

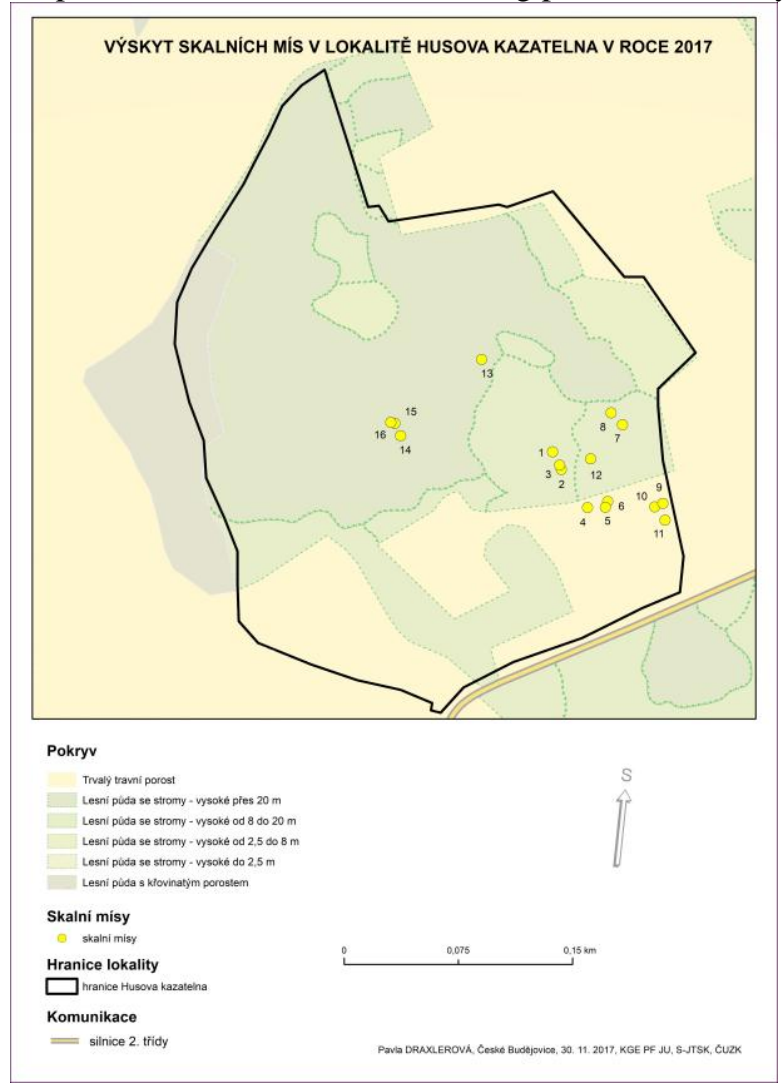

Zdroj: Autori, 2017 
Nejnápadnější mísou ve výrazném destruktivním stavu je mísa na viklanu, kde byly zaměřeny ještě další dvě menší mísy. Ostatní mísy byly zjištěny na rozptýlených balvanech ve směru J-V a S-Z. Z toho třikrát byly zjištěny na jednom balvanu dvě mísy ( $2 x$ těsně vedle sebe, 1x kaskádové propojení), jednou skalní mísa s vodou a jednou spojení dvou skalních mís do vanovitého tvaru. Největší mísa v lokalitě (mísa č. 11) měla rozměry 143 x 106 x $11 \mathrm{~cm}$ a nejmenší mísa (mísa č.14) měla rozměry 14 x 13 x $4 \mathrm{~cm}$.

Bylo změřeno 50 puklin zobrazených na puklinovém diagramu (graf 3), kde převažuje primární směr SSZ-JJV $\left(330^{\circ} / 150^{\circ}\right)$ a sekundární SV-JZ $\left(50^{\circ} / 230^{\circ}\right)$. Oba směry jsou na sebe skoro kolmé. Hodnoty směrů a sklonů den mís byly přeneseny do stereogramu (graf 4), dna vykazují sklon od $0^{\circ}$ do $22^{\circ} \mathrm{s}$ převahou směru V-Z, druhotně ve směru SZ-JV. Při porovnání puklinového systému se směrem a sklonem den skalních mís lze vidět shodu v obecném směru SZ-JV.

Graf 3: Puklinový diagram - lokalita Husova kazatelna Graph 3: The fissure diagram - locality Husova kazatelna

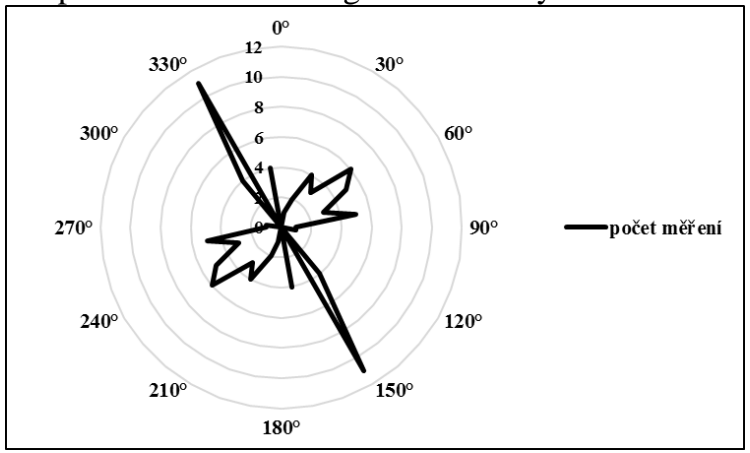

Zdroj: Autori, 2017

Graf 4: Stereogram skalních mís - Husova kazatelna Graph 4: Stereogram of Weathering pits - Husova kazatelna

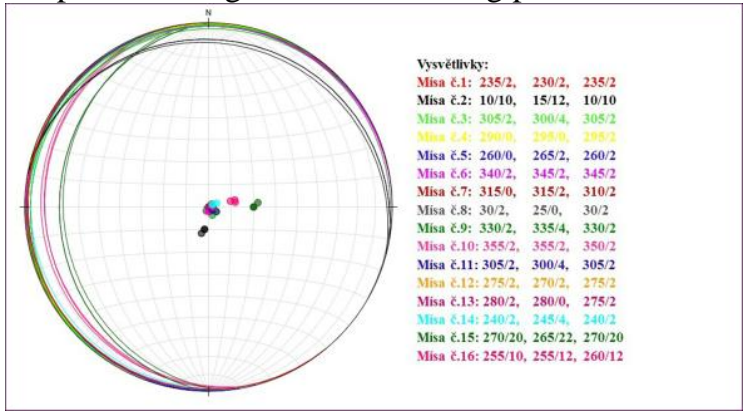

Zdroj: Autori, 2017 


\section{Čertovo břemeno}

Samotnou lokalitu tvoří tor, který se nachází na tzv. Cunkovském hřbetu a který leží mezi osadami Cunkov a Ounuz, asi 3 km jižně od obce Sedlec-Prčice (Vítek, 2004). Strukturní hřbet (714 m n. m.) se nachází v zalesněném prostoru (Demek, Mackovčin a kol., 2006). Na severní straně je tor zcela pokryt mechem a drobnou vegetací, táhne se odtud svahová sníženina. Na východní straně je patrný systém puklin díky deskovité odlučnosti. Západní strana toru je nižší, částečně nesourodého tvaru, a navazuje na volně roztroušené balvany, které pak přecházejí ve větší seskupení. $\mathrm{K}$ jižní straně toru vede nejschůdnější prrístupová cesta.

Bylo zde zjištěno 9 skalních mís. Polohu skalních mís znázorňuje mapa 4. Většina skalních mís se nachází na hlavní části toru, na malém skalním převisu (JV). Jedna skalní mísa byla zjištěna na vrcholové části toru (severní část plochy), jedna mísa na jižní stěně toru a jedna skalní mísa na severozápadní straně nižší části toru. Byly zde skalní mísy s odtokovým žlábkem i bez žlábku, jednou zaznamenáno kaskádové propojení. Největší mísa v lokalitě (mísa č. 6) měla rozměry 54 x 37 x $13 \mathrm{~cm}$ a nejmenší mísa (mísa č. 2) měla rozměry 12 x 9 x $5 \mathrm{~cm}$.

Mapa 4: Výskyt skalních mís v lokalitě Čertovo břemeno v roce 2017 Map 4: The occurrence of weathering pits in the locality Čertovo bremeno in 2017

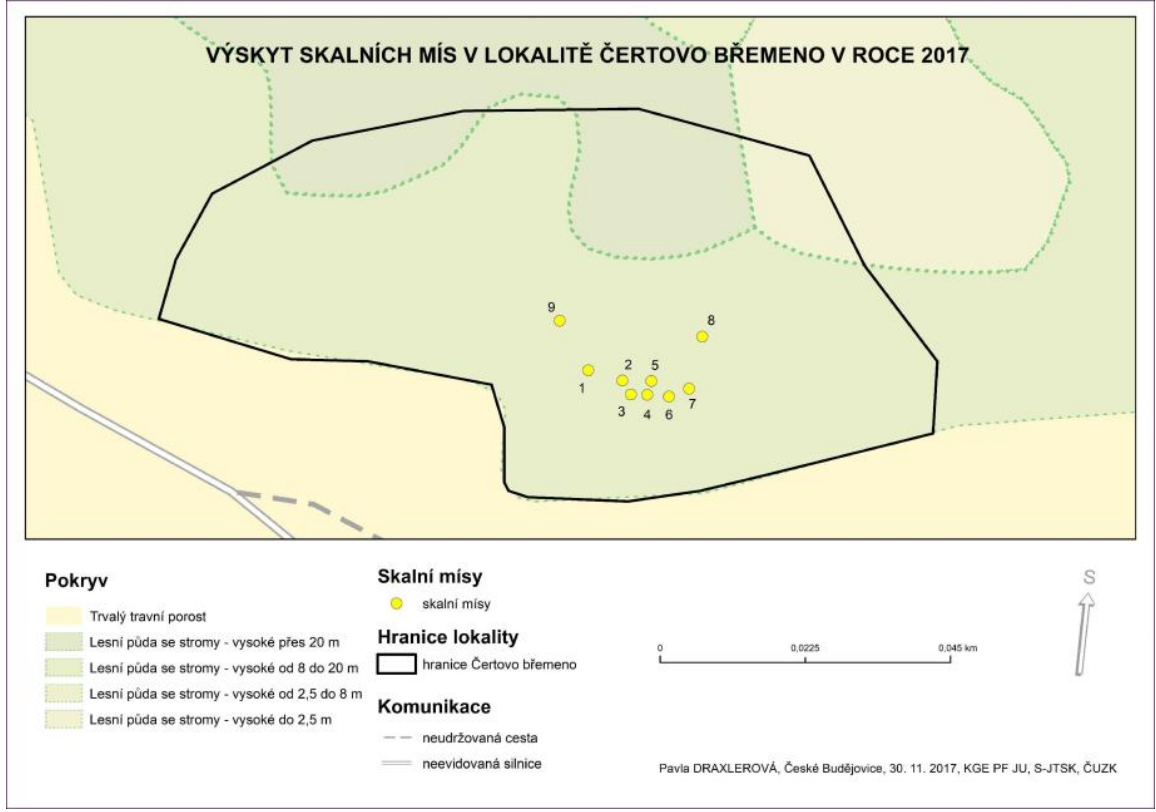

Zdroj: Autori, 2017 
V lokalitě bylo změřeno 100 puklin zobrazených na puklinovém diagramu (graf 5), kde převažuje primárně směr s největším počtem puklin SSZ-JJV $\left(330^{\circ} / 150^{\circ}\right)$ a sekundární směr V-Z $\left(80^{\circ} / 260^{\circ}\right)$. Oba směry jsou na sebe skoro kolmé. Původní tři naměřené hodnoty směrů a sklonů den skalních mís byly přeneseny do stereogramu (graf 6). Dna skalních mís vykazují sklon od $0^{\circ}-16^{\circ}$ $\mathrm{v}$ převaze směru V-Z a druhotně ve směru VSV-ZJZ. Při porovnání puklinového systému se směrem a sklonem den mís lze zjistit poměrnou shodu ve směru V-Z.

Graf 5: Puklinový diagram - lokalita Čertovo břemeno Graph 5: The fissure diagram - locality Čertovo břemeno

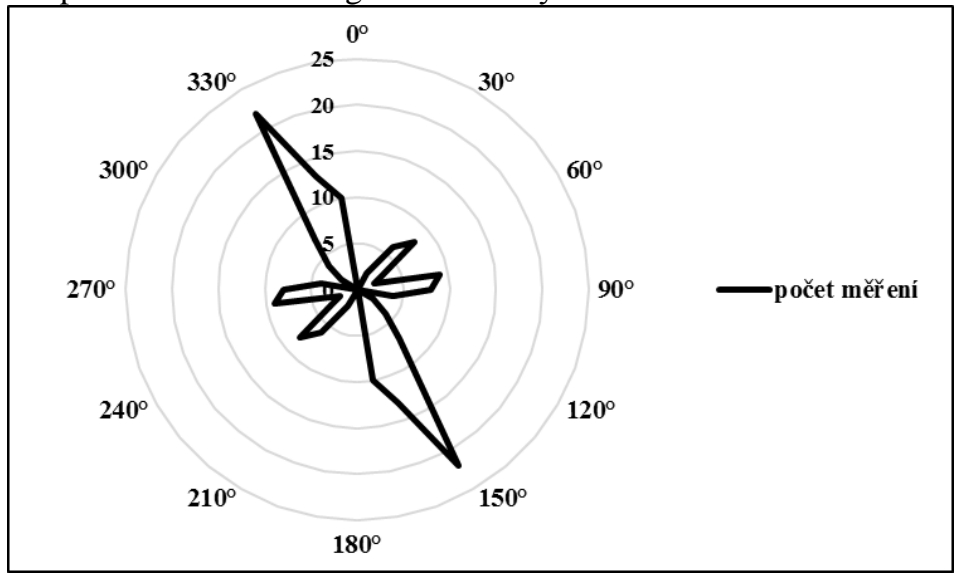

Zdroj: Autori, 2017

Graf 6: Stereogram skalních mís - Čertovo břemeno

Graph 6: Stereogram of Weathering pits - Čertovo břemeno

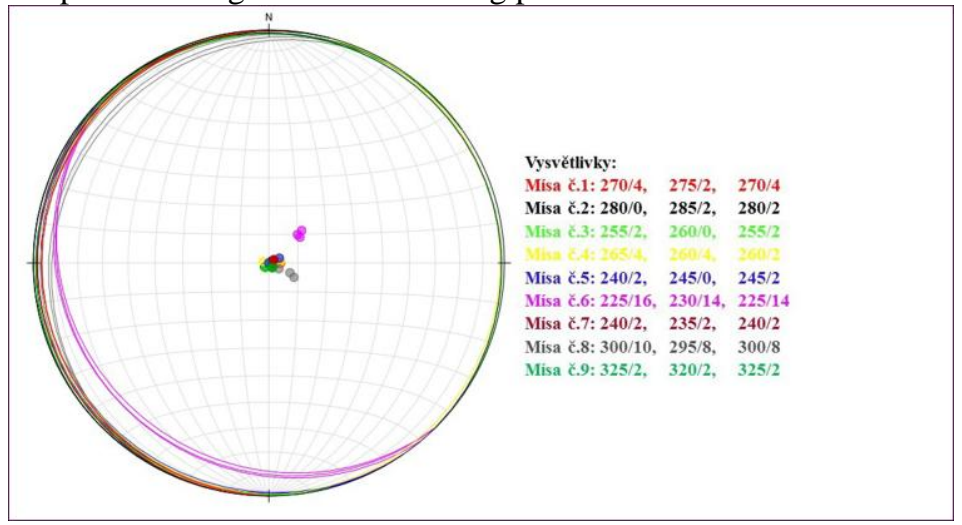

Zdroj: Autori, 2017 


\section{Diskuse}

Hypotézy byly ověřeny při terénním průzkumu a bylo zjištěno, že první hypotéza zaměřená na nehomogenitu horniny byla potvrzena, nebot' geologickým podkladem všech lokalit jsou porfyrické amfibol-biotitické žuly typu Čertovo břemeno, které podléhají rychlejšímu zvětrávání (Chábera, 1982; ČGS, 2010). $\mathrm{Z}$ mineralogického hlediska jsou základem křemenné krystaly, živce, plagioklasy a slídy (Drábek, 2007; Petránek a kol., 2016), které mají různou schopnost rozkladu. Např. krystaly křemene a živce jsou vůči zvětrávání více odolnější než plagioklasy a slídy (Migoń, 2006). V jednotlivých lokalitách byly zjištěny mísy různých velikostí. Důkazem zvětrávání bylo zjištění větších rozměrů skalní mísy na viklanu Husova kazatelna od doby, kdy ji poprvé charakterizuje Chábera (1955) jako mísovitou prohlubeň o průměru kolem $80 \mathrm{~cm}$ a o hloubce přibližně $60 \mathrm{~cm}$. Terénním průzkumem byly zjištěny rozměry 114 x 107 x $64 \mathrm{~cm}$, což odpovídá za 62 let možnosti zvětrávání, kdy autoři předpokládají postupné zvětrávání např. 0,3 - $1 \mathrm{~cm}$ (Demek, 1971) nebo 0,1 - 0,5 cm za rok (Migoń, 2006).

Druhá hypotéza postavená na přítomnosti mechů a lišejníků byla rovněž potvrzena. Průzkumem bylo zjištěno, že mech a lišejník rozrušují horninu a tím způsobují odlupování vrstev a rozpad horniny (Twidale, 1971; Norwick, 2012). V lokalitách Kněz u Hrazan a Husova kazatelna byly objeveny pod vrstvou mechu a dalšího biologického materiálu jak větší, tak menší skalní mísy. V lokalitě Kněz u Hrazan byly zjištěny pod vrstvou mechu mísy s uvolněnými většími kousky žuly, což dále svědčí o propojenosti nehomogenity horniny spolu s procesy zvětrávání, nap̌r. mechanickém, kdy kořínky rostlin rozrušují horninu (Demek 1987). Po odloupnutí kousku mechu a lišejníku z viklanu Husova kazatelna, byla zřetelně vidět na koříncích uchycená drobná zrnka horniny.

Třetí hypotéza o prrítomnosti stálé hladiny vody, která napomáhá zvětrávání mís (Chábera, 1961; Migoń, 2006) má své opodstatnění k souhlasu, nebot' voda funguje jako prvek mechanického a chemického zvětrávání. Při zamrznutí tlačí led na dno a stěny mísy (Pavlíček, 2005), tlakem tak dochází k mikroskopickým puklinám, které jsou předpokladem $\mathrm{k}$ dalšímu zvětrávání. $\mathrm{V}$ tekutém stavu je voda prostředím pro hydrolýzu, výměnu kationtů (Demek, 1987) nebo díky změně pH vyvolanou zbytky odumřelých rostlin, které se hromadí na dně mís, urychluje zvětrávání (Chábera, 2000). Proto je předpoklad, že voda narušuje povrch porfyrické amfibol-biotitické žuly v šetřených lokalitách. Při přeplňování skalní mísy vodou dochází $\mathrm{k}$ přelivům vody $\mathrm{v}$ určitém směru, která pomalu formuje odtokový žlábek. V tomto př́padě se podle Votýpky (1964) vytváŕí třetí stádium vývoje skalní mísy. Ve všech lokalitách byly objeveny také skalní mísy s odtokovým žlábkem, např. v lokalitě Kněz u Hrazan měly všechny zjištěné skalní mísy odtokový žlábek o různé širrce bez ohledu na jejich velikost.

Čtvrtá hypotéza ve studované oblasti nebyla potvrzena. Z terénního průzkumu vyplynulo, že na toru Čertovo břemeno bylo zjištěno jen 9 skalních mís, 
zatímco v lokalitě Husova kazatelna (samostatné balvany) bylo zjištěno 16 skalních mís, tím byl vyvrácen názor Migońa (2006) o větším počtu skalních mís na toru oproti samostatným balvanům.

\section{Závěr}

Studie vychází $\mathrm{z}$ výsledků měření provedených $\mathrm{v}$ rámci terénního průzkumu, který byl součástí bakalářské práce na téma - Skalní mísy Votické vrchoviny. Pro účely studie byly vybrány souhrnné informace o obecné charakteristice výskytu skalních mís $v$ jednotlivých lokalitách a hodnoty spojené se směrem a sklonem den skalních mís a puklinového systému, jenž zobrazují jednoduché stereogramy a puklinové diagramy. Na základě jejich porovnání byla zaznamenána shoda orientace den skalních mís v dané lokalitě s orientací daného puklinového systému v obecných směrech (např. SV-JZ, SZ-JV).

Z terénního průzkumu dále vyplynulo, že i když každá lokalita má svá specifika a své odlišnosti, přesto v nich převládaly skalní mísy různých velikostí, jak s odtokovým žlábkem o různé šířce, tak bez odtokového žlábku. $Z$ celkového počtu zjištěných skalních mís (34) byla více než polovina skalních mís s odtokovým žlábkem, tj. ve vysokém stupni vývoje. Podle charakteristiky Votýpky (1964) odpovídaly třetímu a čtvrtému stupni vývoje, což také souvisí se shodným geologickým podložím lokalit, tj. porfyrická amfibol-biotitická žula typu Čertovo břemeno (Chábera, 1982; ČGS, 2010), která podléhá rychlejšímu zvětrávání. V rámci měření puklinového systému bylo změřeno celkem 212 puklin.

Studie přinesla nová zjištění o výskytu skalních mís a poprvé byly zaměřeny a změřeny všechny zjištěné skalní mísy ve vybraných lokalitách. Výsledky studie podaly ucelenější informace o výskytu skalních mís ve vybraných lokalitách Votické vrchoviny, které mohou posloužit jako podklad pro další zpracování o výskytu a stavu skalních mís na našem území.

\section{Poděkování}

Př́spěvek vznikl za podpory grantu Jihočeské univerzity v Českých Budějovicích c. 160/2016/S: "Kličové kompetence $v$ kontextu mezioborových vazeb přrodovědných predmětü".

\section{Literatura}

CULEK, M. a kol. 2013. Biogeografické regiony České republiky. Brno: Masarykova univerzita, 2013. 447 s. ISBN 978-80-210-6693-9.

ČGS 2010. Vyhledávání - Kněz u Hrazan [online]. 2010, [cit. 2017-04-29].

Dostupné na internetu: <http://lokality.geology.cz/d.pl?item=7\&id=492\&

Okres=PI\&vyb=1\&text=Lokality\%20v\%20okresu>. 
DEMEK, J. 1987. Obecná geomorfologie. Praha: Academia, 1987. $476 \mathrm{~s}$.

DEMEK, J. 1971. Skalní mísy a jejich geneze. In Geologický pri̊zkum. ISSN 0016-772X, 1971, roč. 13, č. 2, s. 53-54.

DEMEK, J. a kol. 1987. Zeměpisný lexikon ČSR. Hory a nižiny. Praha: Academia, 1987. $584 \mathrm{~s}$.

DEMEK, J. - MACKOVČIN, P. a kol. 2006. Zeměpisný lexikon ČR. Hory a nižiny. 2. vyd. Brno: AOPK ČR, 2006. 582 s. ISBN 80-86064-99-9.

DRÁBEK, K. 2007. Naučné stezky a trasy II. Jihočeský kraj. Praha: Dokořán, s.r.o., 2007. 304 s. ISBN 978-80-7363-076-8.

GOUDIE, S. A. 2004. Encyclopedia of Geomorphology. J-Z. vol. 2. London: Roultedge Ltd, 2004. 1156 p. ISBN 0-415-32738-5.

HUGGETT, R. J. 2007. Fundamentals of Geomorphology. 2. ed. London and New York: Routledge, 2007. 458 p. ISBN 0-203-94711-8.

CHÁBERA, S. 2000. Obětní mísy žádné oběti nepamatují : Geologické zajímavosti jižních Čech. In Českobudějovické listy. 2000, roč. 9, č. 286, př́loha Nedělní kanape, s. 5.

CHÁBERA, S. 1992. Žulové balvany se skalními mísami na Kovářovsku. In Sborník Jihočeského muzea v Českých Budějovicich - Přirodní vědy. České Budějovice: Jihočeské muzeum, 1992. ISSN 0139-8172, roč. 32, s. 5-11.

CHÁBERA, S. 1982. Geologické zajímavosti jižních Čech. České Budějovice: Jihočeské nakladatelství, 1982. $160 \mathrm{~s}$.

CHÁBERA, S. 1961. Mísovité vyvětrávání žuly v jižních Čechách. In Sborník Krajského vlastivědného muzea v Českých Budějovicích - Přrirodní vědy. České Budějovice: Jihočeské muzeum, 1961. ISSN 0139-8172, roč. 3, s. 51-67.

CHÁBERA, S. 1955. Žulové viklany v okolí Petrovic a Krásné Hory. In Lidé a země. ISSN 0024-2896, 1955, roč. 4, č. 8, s. 352.

CHÁBERA, S. a kol. 1985. Neživá př́roda. České Budějovice: Jihočeské nakladatelství, $1985.270 \mathrm{~s}$.

CHLUPÁČ, I. a kol. 2002. Geologická minulost České republiky. Praha: Academia, 2002. 436 s. ISBN 80-200-0914-0.

MIGOŃ, P. 2006. Granite Landscapes of the World. Oxford: Oxford University Press, 2006. 384 p. ISBN 0-19-927368-5.

NORWICK, J. 2012. Lessons from a Mixed Deterministic Stochastic Model of Periglacial Gnamma Development [online]. 2012, [cit. 2017-05-13]. Dostupné na internetu: <https://sonoma-dspace.calstate.edu/handle/10211.1/1426>.

PAVLÍČEK, V. 2005. Skalní mísy Novohradských hor a jejich podhưří. In Geomorfologický sborník 4. Stav geomorfologických výzkumů v roce 2005. České Budějovice: Jihočeská univerzita, 2005. ISBN 80-7040-763-8, s. 129-134.

PETRÁNEK, J. a kol. 2016. Encyklopedie geologie. Praha: Česká geologická služba, 2016. 352 s. ISBN 978-80-7075-901-1.

QUITT, E. 1970. Mapa klimatických oblastí ČSSR. Praha: Kartografické nakladatelství, 1970. 
RUBÍN, J. - BALATKA, B. a kol. 1986. Atlas skalnich, zemních a půdních tvarů. Praha: Academia, 1986. 388 s.

RYPL, J. - KIRCHNER, K. - BLAŽEK, M. 2017. The spatial distribution of rock landforms in the Pohořská Mountains (Pohořská hornatina) Czech Republic. In Acta Geographica Slovenica. vol. 57, no. 2, pp. 45-55. DOI: http://dx.doi.org/10.3986/AGS.1184.

RYPL, J. - KIRCHNER, K. - DVOŘÁČKOVÁ, S. 2016. Geomorphological Inventory as a Tool for Proclaiming Geomorphosite (a Case Study Mt. Myslivna in the Novohradské hory Mts. - Czech Republic). In Geoheritage. vol. 8, no. 4,p p. 393-400. DOI: https://dx.doi.org/10.1007/s12371-015-0169-5.

TOMÁŠEK, M. 2007. Půdy České republiky. 4. vyd. Praha: Česká geologická služba, 2007. 68 s. ISNB 978-80-7075-688-1.

TWIDALE, C. R. 1971. Structural Landforms. vol. 5. Canberra: Australian National University Press, 1971. 247 p. ISBN 0-7081-0733-8.

UHUL 2001. Textová část oblastního plánu rozvoje lesů, část A. Přrodní lesní oblast č. 10 Středočeská pahorkatina [online]. 2001, [cit. 2017-09-15]. Dostupné na internetu: <http://www.uhul.cz/images/ke_stazeni/oprl_oblasti/ OPRL-LO10-Stredoceska_pahorkatina.pdf >.

VÍTEK, J. 2004. Tajemný svět skal : Skalni zajímavosti České republiky. Ústí nad Orlicí: OFTIS, 2004. 192 s. ISBN 80-86845-03-6.

VLČEK, V. a kol. 1984. Zeměpisný lexikon ČSR. Vodní toky a nádrže. Praha: Academia, 1984. $316 \mathrm{~s}$.

VOTÝPKA, J. 1964. Tvary zvětrávání a odnosu žuly v severní části Novobystřické vrchoviny. In Sborník ČSSZ. Praha : Nakladatelství Československé akademie věd, 1964. ISSN 0036-5254, roč. 69, č. 4, s. 243-258.

\section{WEATHERING PITS OF VOTICKÁ HIGHLANDS}

\section{Summary}

Weathering pits are an interesting rock form that attracts the attention of both experts and the general public. Even today, for many people, they are a mysterious rock form that is a part of a number of legends, with various theories of their origin or use. Apart from legends, there are also historic records of their practical use. According to available records, some the weathering pits in the forests around the Vltava River were used to grind the grain of corn at the time of the Thirty Years War or in the vicinity of Milevsko to burn the tar (Chábera, 2000).

The study presents a part of the results from the field work, which was part of the Bachelor Thesis on the theme - Weathering pits of Votická vrchovina Highlands. And deals with the occurrence and status of the weathering pits in the 
Votická vrchovina Highlands, it is area that have not yet been independently and completely researched.

The Votická vrchovina Highlands with an area of $501.12 \mathrm{~km}^{2}$ is located in the western to southwest part of the Vlašimská hilly area (Demek, Mackovčin et al., 2006). It is a slightly undulating landscape with an average height of 500-600 $\mathrm{m}$ n.m., which is the remainder of the formerly aligned surface, strongly damaged by fractures with distinct structural ridges with protruding more resistant rocks in the form of knots or massive blocks (boulders, viklanes, menhirs) (Chábera et al., 1985; Demek, Mackovčin et al., 2006).

In selected localities (Kněz u Hrazan, Husova kazatelna a Čertovo břemeno) a total of 34 weathering pits were found and measured. Among the important characteristics were: dimensions of weathering pits (length, width, depth) and direction and slope of weathering pits. The development stages of weathering pits are mentioned in Votýpka (1964) and according to his findings there are mainly weathering pits in the third and fourth stage of development in selected localities. A total of 212 fissures were also measured. The results of the fissure system measurement and direction and slope of the bottoms of weathering pits were processed into fissure diagrams and stereograms. Based on their comparison, the question was answered: whether it matches or not the orientation of the bottoms of the weathering pits matches the orientation of the fissure system in the given locality. In most cases they were matching.

The results of study can be used as a source of information for the creation of a publication about the occurrence of weathering pits in the Votická vrchovina Highlands or the territory of the Czech Republic, or as a source for educational and tourist purposes.

\section{Bc. Pavla Draxlerová}

Př́rodovědecká fakulta

Univerzita Karlova v Praze

Albertov 6, 12843 Praha

E-mail: pavla.draxlerova@natur.cuni.cz

\section{Mgr. Jiř́i Rypl, Ph.D.}

Pedagogická fakulta

Jihočeská univerzita v Českých Budějovicích

Jeronýmova 10, 37115 České Budějovice

E-mail: rypl@pf.jcu.cz 